\title{
A Study on the Future of World Leader's Behaviour towards Global Health after COVID-19
}

\author{
Gururaj Itagi ${ }^{1}, \&$ P. S. Aithal ${ }^{2}$ \\ ${ }^{1}$ Research Scholar, Srinivas University, Mangalore, Karnataka, India. \\ Email: gururajitgi@gmail.com \\ ${ }^{2}$ College of Management \& Commerce, Srinivas University, Mangalore, Karnataka, India. \\ Email: psaithal@srinivasgroup.com
}

Area of the Paper: Management.

Type of the Paper: Exploratory Analysis.

Type of Review: Peer Reviewed as per $|\mathrm{C}| \mathrm{O}|\mathrm{P}| \mathrm{E} \mid$ guidance.

Indexed In: OpenAIRE.

DOI: http://doi.org/10.5281/zenodo.3839765.

Google Scholar Citation: IJCSBE.

\section{How to Cite this Paper:}

Itagi, Gururaj, \& Aithal, P. S. (2020). A Study on the Future of World Leader's Behaviour towards Global Health after COVID-19. International Journal of Case Studies in Business, IT, and Education (IJCSBE), 4(1), 127-135. DOI: http://doi.org/10.5281/zenodo.3839765.

International Journal of Case Studies in Business, IT and Education (IJCSBE) A Refereed International Journal of Srinivas University, India.

(C) With Authors.

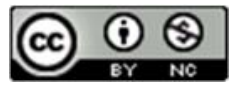

This work is licensed under a Creative Commons Attribution-Non-Commercial 4.0 International License subject to proper citation to the publication source of the work.

Disclaimer: The scholarly papers as reviewed and published by the Srinivas Publications (S.P.), India are the views and opinions of their respective authors and are not the views or opinions of the S.P. The S.P. disclaims of any harm or loss caused due to the published content to any party. 


\title{
A Study on the Future of World Leader's Behaviour
}

\section{towards Global Health after COVID-19}

\author{
Gururaj Itagi ${ }^{1}, \&$ P. S. Aithal ${ }^{2}$ \\ ${ }^{1}$ Research Scholar, Srinivas University, Mangalore, Karnataka, India. \\ Email: gururajitgi@gmail.com \\ ${ }^{2}$ College of Management \& Commerce, Srinivas University, Mangalore, Karnataka, India. \\ Email: psaithal@srinivasgroup.com
}

\begin{abstract}
Healthy citizens always stay as support for the overall growth and development of any nation. The overall behaviour of the leader plays an important role to lead the whole mankind together towards a secured, healthy and future-oriented life. If there is the positive behavioural response between the people, between leader and citizens of a nation, between leaders in the glob and between the people on the earth the whole mankind come united and live supportively, collaboratively and happily without any problems. The study noted that the lack of appropriate behaviour preparedness among the world leaders and collaborative efforts to fight against any global health challenges are the reasons to be failures to ensure a secured and healthy life for the mankind on the earth. To this to happen the world leaders should adopt change in their behaviour as positive oriented, cooperative and human and eco-friendly. They should stop fighting each other for dignity, power and to have hold on each other. So that we can expect good global health and more strength to fight against any future challenges that come to mankind.
\end{abstract}

Keywords: World Leader's Behaviour, Global Health, Future Global Challenges, COVID19, Pandemics, Manmade Calamities and Natural Calamities.

\section{INTRODUCTION :}

Health is one of the basic assets of mankind that stimulates the potentiality and the human interest to step up for leaving a better life. The better is nothing other than having a life full of happiness which comes from satisfying the human emotions. That may even happen through just sharing a piece of bread to someone hungry. But the human ego never stood only satisfying his emotions it extended tragically to dominate the supreme power of nature. The nature making mankind to understand its power through different natural calamities for several years. And it discards whatever is against the system of nature and makes human realize his roles and responsibilities towards being beneficial to the whole. The calamities are categorized into two parts one man-made and the other one is natural calamities. But there is a reason from nature behind all the calamities either by the man or by nature. Even there is also a contribution by the human behind all the calamities either by the man or nature which is been also pushed into the sufferings of the other species on the earth.

Trees are dominant on the earth of biomass consisting of 82 per cent. The human account is just 0.01 per cent of the biomass on the earth and 95 per cent of these population on the earth lives on just 10 per cent of the land [1] [2]. But, the only 0.01 per cent of human presence on the earth challenging the whole system of nature and dominating all the other biomass on the earth and under the ocean. Overpopulation, Pollution, Global Warming, Climate Change, Ocean Acidification, Water Pollution, Deforestation, Acid Rain and Ozone Depletion are few major results of the human impact towards nature due to acquisitive motive, desire to own large amounts of money and property, changed behaviour to the over expectation of the living comfort and human competition. Urbanization, globalization and modernizations are the three major windows through which the human converted his behaviour totally against nature desired behaviour [3]. 
The leadership of any country also influences the overall behaviour of the citizens. From the age when human got civilized to the 21 st century, the drastic changes in human behaviour can be noticed and such undesired behaviour of development has directly or indirectly contributed to the harm of nature. Such contribution of mankind to the harm of the nature reflected several times through different calamities. But we humans never learnt a lesson whenever that is been taught by nature. The world leaders started a competition that has happened ever before resulting through the innovations and dominance on the other species on the planet earth. Inappropriate behaviour of the world leaders towards nature may take the whole of mankind against nature and get discarded. The current behaviour of the human is very crucial that may close the window of political, social, physical, psychological and environmental wellbeing opportunities of the days to come tomorrow. These irreversible trends in the global leader's behaviour will certainly pull mankind at the risk of a sudden disaster such as COVID19. Such disasters erode the earth's life as well as discards the species against nature [5] [38] [39].

The severe need to fulfil the gaps in our understanding of the dynamics of ecosystems as well as making our effort to investigate and understand the human nature of decision-making against the supreme power of nature. It is also a time to question ourselves how our egoistic behaviour and desire to have a competent and comfort life through innovations are causing tragic loss of the biodiversity. Unless the national leadership influences its citizen's behaviour towards being cooperative to the cycle of the ecosystem. The national leaders should also require to change their competitive nature towards global leadership and end their desire of fulfilling the political thirst. Unless this has happened the life of mankind in the globe remains elusive [4] [40].

\section{OBJECTIVES OF THE STUDY :}

The description of the whole study is mainly done under the following objectives. Firstly, the study is to describe various pandemics and calamities. It is also to understand the present and future challenges of COVID-19 and to explore the future challenges for world leader's behaviour and global health. Another important objective of the study is to explore and suggest the need for change in the world leader's behaviour.

\section{METHOD OF THE STUDY :}

The study is descriptive in nature. It analyses the existing reports of various pandemics, calamities and other health-related issues been proposed by various departments, government and non-government authorities. The study is done mainly using secondary data referring to various books, research articles, journals and seminar presentations from Google Scholar, SSRN, Academia.edu, Shodhganga and Zenodo. The study also analyses various news media articles and reports.

\section{CALAMITIES AND THEIR IMPACTS ON BEHAVIOUR CHANGE :}

We, humans, witnessed several calamities both natural and manmade since from the beginning when mankind existed. In decades these calamities brought a drastic change in human thinking and altered his behaviour to challenge nature. Let us look into the impact of some natural and manmade calamities on the behaviour of world leaders.

\subsection{First World War:}

The World War-I has taken place with the inappropriate decision taken by leaders of different nations. Mainly the way different nations behaved each other to prove their dominance and satisfy their ego. World War I took place between two groups of nations the first group was Central powers including Germany, Austria- Hungary, Italy, and Turkey. The group second was Allied powers including Russia, France, Great Britain, and the United States. The main cause for World War I was alliance system. As per this system, different countries were in alliances that they help each other when they are in need. Germany had a secrete alliance with Austria-Hungary so the time when Germany declared war all other countries that are under alliance also announced war. This one system of alliance lately ended up with total War Casualties about 40 million deaths and this tragic incident become a deadliest dispute in human history [6] [7].

Even though the world was not technologically well developed to produce highly effective weapons all nations involved in the war used more than one type of weapons and aircraft. In spite of all the casualties, the world leaders were again in competition to strengthen their armed forces and own an 
effective weapon system. The leader's behaviour was not changed by the experience of the great human tragedy after the First World War. Even though there was a big loss of civilians and soldiers, there was no effort by the leaders to give them a long time of protection and healthy life. This war has passed a message to the glob that all the nations must learn to be ready to face any future challenges through the wars [8] [9].

4.2 Second World War:

Around 21 years later from the First World War the whole world becomes a witness to another tragedy of World War II. World War 2 was started in 1939 when Germany invaded Poland. Great Britain and France also retaliated declaring war against Germany. The main war was between Axis powers and Allies. The impact of the Second World War was much greater than ever before. Around 75 million people were dead including 40 million civilians. But the tragedy behind the death was that the deliberate genocide, mass-killing, mass-bombings, disease, famine, and starvation. The behaviour of world leaders never changed with the tragic incident of World War I, they were more dominant ever before, competing with each other for power and control. So, they were busy preparing their nations to be a supreme power of the world. The rise of militarism both in Germany and Japan, the economic depression across the world and is not able to convince, cooperate and work together for the betterment of the globe became a pathway for the great battle to destroy the wellbeing of the innocent people. This indicates the failures of leadership and their behavioural reaction towards the appropriate success of mankind on the planet earth [12] [13].

For the first time in history, nuclear weapons were used in the battle which destroyed the hopes of the people living in Japan. Around 2.5 lakh people were killed in this attack and till today the effect of the bombing is been faced by citizens of Japan [11]. The Second World War created a significant impact on the United States. The Workforce got distracted, the economy came down, and its unemployment rate raised. The horror of the war also created its hall-mark on the young people of different nations in which they lived. The young children witnessed horrendous crimes against innocent people, soldiers and humanity were committed in the war. The battle even altered the political and economic systems permanently in many countries [10] [14].

Only five states had nuclear weapons during the Second World War such as the United States, the U.S.S.R., Great Britain, France and China. But the use of nuclear weapons in the Second World War created a fear among the leaders of different nations and made them be in a competition of owning such weapons. The big impact of the Second World War not even made these leaders realize their mistakes and change their behaviour towards global competition. Today many countries in the globe are competing for each other to own the nuclear weapons, strengthen their military forces, it looks like they all preparing to the future war which may destroy the mankind on the earth [11] [15].

\subsection{Various Pandemic Diseases:}

The whole world witnessed several pandemics in its history. Bubonic plague, Influenza, Smallpox, Yellow fever, and Cholera are some examples of deadly pandemics in the history of mankind. These brutal killer diseases destroyed billions of lives across the world. Smallpox killed around 300 to 500 million people in its existence of 12,000 years. From 1918 to 1920 the other pandemic disease called Spanish flu infected 500 million people in its 36 months of existence. All these pandemics killed billions of people, entering every nation, infecting without partiality between rich, poor and any religion or cast. Political change, social imbalance, or economic fluctuations are the major reasons for all the occurrence of pandemics. When different empires were brought together by the various leaders through their conquest that has facilitated the spread of different pandemics [18] [19]. Even though the Human immunodeficiency virus (HIV) been identified in Africa in the year 1940 but it was not spread to the world at that time. When the boundary of the nations changed and millions of people moved from one place to another after the civil wars between 1960 and 1970 the HIV also got spread to the world [16].

Most of these deadly pandemics transmit from insect to humans such as mosquitoes, flies, ticks, and some other bloodsucking insects. Some diseases get transmitted from animal to human such as H5N1, Rabies, Kyasanur Forest Disease (KFD). The KFD which is also called as monkey fever transmitted from monkey to human which is killing helpless poor civilians in the southern part of Karnataka state in India and the SARS virus which killed many people in recent years are also some examples for such pandemics [17]. Many of these brutal experiences of various pandemics have never changed the 
behaviour of our national leaders. They never expressed their strong stand to work effectively and to provide a safe and healthy life. They never worked collaboratively to build unity of among mankind in the world and they never encouraged their people to be responsible and part of nature. The leaders never worked sincerely to set up an appropriate methodology that could reduce the great human loss in all calamities after several experiences.

\subsection{Indian OceanTsunami-2004:}

One more edition to the list of disasters from human history was The Indian Ocean Tsunami in 2004. This deadliest earthquake occurred on the west coast of northern Sumatra, Indonesia. The killer waves rushed across 14 countries and killed around 230,000 people. This earthquake was the third-largest earthquake of the world. However, these are the few examples of human tragedies from history. If you look behind all these calamities there was a direct or indirect contribution of mankind and nature taught them a lesson. The tsunami may be a natural calamity but if the national leaders would have behaved responsibly and the respective officials would work sincerely in all the affected countries then they could have rescued the innocent people who were killed throughout the coastal areas of all the countries. We just reconstructed all the loss but never understood the serious need of our responsibilities towards protecting nature and behave as a part of the whole universe [20] [21] [22].

\subsection{Coronavirus Disease 2019 (COVID-19):}

There was a good intention among the national leaders for providing quality medical care and health protection to the people on the planet earth. But this human initiation in the field of innovation of various medicines and medical-related technologies has come today to the peak of generating the biochemical weapons! Over the period human behaviour has drastically changed from positive intentions to negative intention. An example of this change in the behaviour of a leader is Coronavirus Disease 2019 also known as COVID-19. The virus is spreading via human to human and it is currently identified as virus basically hosted by bats or other wild animals sold in the seafood market in Wuhan, China [26] [29].

This unknown virus firstly detected between the dates 1st and 3rd December 2019 in Wuhan, China. Later on, 31st December 2019, it was brought to the notice of the World Health Organization. Seeing the severe spread of this virus from human to human the WHO announced a Public Health Emergency on 30 January 2020. The first case outside of China was officially confirmed in Thailand on 13th January 2020. The virus currently spreading in 210 Countries and Territories around the world and by now 3.12 million cases have been confirmed. The deadly virus also killed 218,010 people in different countries around the world [27] [28].

\section{WHAT AFTER COVID-19 :}

Media across the world blamed and criticized China for spreading this deadly virus across the world. Few media also reported that this killing virus is manmade! To fulfil the dream to become the world top country and dominate the success of well-developed and competing countries around the world China has developed this Coronavirus as a Bio-Chemical Weapon. Few media in China also reported that the doctors were criticized by the China government for disclosing the information in the early weeks of this unknown SARS-like virus which was spreading in Wuhan province. A report noticed, by 20th December there were around 60 cases confirmed in China but the information was given to WHO by the end of December. The Corona Virus is also misbalancing the economy, life of civilians and the whole political and social setting in every nation affected. We can understand some of the hidden agenda with the deadly spread of this virus across the world through a critical analysis of the information given above on about COVID-19. China is a country in which the Corona Virus originated and spread across the world. Same China is selling most of the medical equipment to the affected countries. Surprisingly most of the cities in China have not affected by this virus but a country like America even though being around 9000 kilometres away from China is facing a big threat of this virus [30].

Most of the countries are blaming China for not giving appropriate information in time to the world and for being the reason for millions of deaths across the world. Leaders from different country have given statement that if there is an intentional part of China in vide spread of Coronavirus then China is going to face the retaliation. Many countries have already brought changes in their international marketing policy with China and many international companies expressed fear to work in China for 
future days. A discussion in the media about the coronavirus as a Bio-Chemical Weapon developed by China to fight against competing nations is also creating a fear across the world. This concept also may create another platform for the different countries to develop Bio-Chemical Weapons and use them to dominate each other to fulfil their political thirst. These type of behaviour among the world leaders may push mankind once again into the risk of World War [24] [25].

\subsection{The Future of Global Health:}

Global health is not just mental and physical wellbeing of people instead it is overall wellbeing of all the nations in the world including the medical, social, economic and political balance. But today the whole world is facing the imbalance in the Cycle of nature, inappropriate change in human behaviour and the global competition among the nations to become supreme power of the world. As a result of this challenge the killer virus Corona standing before all the nations as a global health threat. The overgrowth of the human population on the earth, the rise of new technologies, urbanization, globalization, deforestation, industrialization and other human contributions for his satisfaction of life are few key factors that are challenging indirectly to the global wellbeing [34].

Nature is already retaliating through its acts such as floods, earthquake, global warming, raise of new disorders, deadly virus spread and many more. If mankind does not stop working against nature and change their behaviour towards the world the problem definitely raises in future [32], [40].

\subsection{Need for Change in the World Leader's Behaviour:}

However, every single nation is engaging their medical experts to invent the vaccine for the killing Coronavirus. The government, administration of each nation, the doctors and nurses, police, social workers, and any other people for medical and emergency service are highly engaging themselves to fight against Coronavirus. In spite of all these efforts, some nations are still unable to protect their people from the threat of Coronavirus. The countries considered as the world most developed and richest nations such as America, German, France, and Italy are highly threatened by this virus and lost thousands of civilians by the Corona spread. The Corona issue has made all these nations to realize the weakness they have to provide appropriate health care, security, social and economic wellbeing to their people. Many nations are highly depending on each other for medical equipment, medical experts, medical technologies and medications. Lack of unity within the nation and between the nations, lack interest among the political leaders and the lack of preparedness are the other side of the challenges they have to fight effectively against COVID-19 and safeguard the innocent people [30].

The country like India lead by Narendra Damodardas Modi has given importance to its people's life instead of giving importance to its economic loss. But some of the nations have not proved it through their taken actions against COVID-19 which shows the clear picture of the irresponsible behaviour of the national leaders to provide appropriate medical care to the people. It seems that they just want supreme power and they would like to enjoy their highness. A leader like Kim Jong-un who is always aggressive and enthusiastic in war may put innocent people into risk. Even though America is one of the richest countries in the world but the leader Donald John Trump who is basically from the business neglected to take quick and effective decisions to fight against Coronavirus and made Americans into the risk of Corona through which more than 60,000 people died. These are the few examples for the need for changes in the behaviour of the world leaders to ensure the protection, high global health and wellbeing for mankind on the planet earth [31].

\subsection{Walk Back:}

Human beings are evolved in the forest so till today we all connected to nature and live as a part of it. When we lived in a joint family system, we were understanding each other better and had a deep humanitarian feeling in us. The human being was respecting nature very well and was feeling to care and protect the other lives on the earth. The human was also highly cooperative with the ecosystem. But after civilization, the human started dominating the other species on the planet earth. This dominance resulted in the rise of new leaders across the world. The competition for the power and legacy started from the rise of new leaders. Through our capacity of thinking, gained knowledge and innovations we always thought that we can stand against nature and prove our supreme power on the earth [36].

It is a time to step back to nature, be cooperative to the eco cycle, support and protect other species on the planet earth for their free-living, reduce the speed of our development process, adopt a humanitarian approach, love and respect each other. It is also a time to get united and cooperate with each other for 
the wellbeing of mankind on the earth. These are some opportunities through which human can safeguard him selves and others. Mankind is not safe unless our world leaders behave cooperative, selfless and supportive to each other [37].

\subsubsection{Areas to make change}

$>$ Encouraging people to be cooperative to nature through effective policies and programs.

$>$ Understanding future challenges in global health and wellbeing and change the mindset of being not responsible for it.

$>$ Bring the alteration in the present policies and develop new policies which should also consider a long-term result in the wellbeing of mankind and the other species on earth.

$>$ Working together internationally for sharing knowledge, support and cooperation.

$>$ Making a difference between present and future living with sustainable efforts in the development process.

$>$ Giving more importance to developing career opportunities even in supportive areas of nature.

$>$ Gain the appropriate support from citizens living in and outside of the country and also from leaders in different nations for the overall change.

$>$ Adopt good emotional intelligence which helps the leaders to control their own behaviour and mood, have better self-understanding, decision making, and develop motivation and empathy and to adopt good social skills.

$>$ Build a good economic, political, social, cultural and educational network across the world.

$>$ Give importance to leadership development in the country.

$>$ Create or join a multinational organization which will create a platform to develop a better international relationship, support and cooperation.

$>$ Stop invalidating other leaders or person's power, thought or effort inside or outside of the country.

$>$ Understand the present challenges that we have for the quality life, good health and wellness of all species on the earth. Participate actively in a problem-solving process through effective projects, programs and continues effort.

$>$ Stop the projects, programs or any other policies which are against the eco cycle and which will also create a long-term effect on the earth and other species living on it [3] [33] [35].

\section{CONCLUSION :}

The study noted that the lack of appropriate behaviour preparedness among the world leaders and collaborative efforts to fight against any global health challenges are the reasons to be failures to ensure a secured and healthy life for the mankind on the earth. Healthy citizens always stay as support for the overall growth and development of any nation. The overall behaviour of the leader plays an important role to lead the whole mankind together towards a secured, healthy and future-oriented life. If there is the positive behavioural response between the people, between leader and citizens of a national, between leaders in the glob and between the people on the earth the whole mankind come united and live supportively, collaboratively and happily without any problems. To this to happen the world leaders should adopt change in their behaviour as positive oriented, cooperative and human and ecofriendly. They should stop fighting each other for dignity, power and to have hold on each other. So that we can expect good global health and more strength to fight against any future challenges that come to mankind.

REFERENCES :

[1] Bar-On, Y. M., Phillips, R., \& Milo, R. (2018). The biomass distribution on Earth. Proceedings of the National Academy of Sciences, 115(25). 6506-6511. DOI: https://doi.org/10.1073/pnas.1711842115.

[2] Saisana, M., \& Saltelli, A. (2008). Sensitivity Analysis for the 2008 Environmental Performance Index. European Commission: Fermi. DOI: 10.2788/91982.

[3] Kaplan, S. (2000). New ways to promote pro-environmental behaviour: Human nature and environmentally responsible behaviour. Journal of social issues, 56(3). 491-508.

[4] Milner-Gulland, E. J. (2012). Interactions between human behaviour and ecological systems. Philosophical Transactions of the Royal Society B: Biological Sciences, 367(1586). 270-278. 
[5] Daily, G. C., \& Ehrlich, P. R. (1994). Population, sustainability, and Earth's carrying capacity in Ecosystem Management. Springer, New York, NY. Retrieved from: https://notendur.hi.is/bdavids/UAU_102/Readings/Daily_Ehrlich.pdf.

[6] Michacl Howard (2002). The First World War. Oxford University Press INK. ISBN-0-19-2853627.

[7] Keith Robbins (2002). The First World War. Oxford University Press Inc. ISBN 0-19-280318-2.

[8] Alice Goldfarb Marquis (1978). Words as Weapons: Propaganda in Britain and Germany during the First World War. Journal of Contemporary History, 13(3).

[9] Rodney P. Carlisle (2007). Eyewitness History World War I. Facts on File, Inc. ISBN 0-8160-60614.

[10] Kesternich, I., Siflinger, B., Smith, J. P., \& Winter, J. K. (2014). The effects of World War II on economic and health outcomes across Europe. Review of Economics and Statistics, 96(1), 103118. DOI: 10.1162/REST_a 00353.

[11] Arase, D. (2007). Japan, the Active State? Security Policy after 9//11. Asian Survey, 47(4), 560583.

[12] Reg Grant (2008). World War II. DK Publishing. ISBN: 978-0-7566-3830-6.

[13] Elena Lamberti, \& Vita Fortunati (2009). Memories and Representations of War, the Case of World War I and World War II. Amsterdam. ISBN: 978-90-420-2521-9.

[14] Winston Churchill (2002). Triumph and Tragedy. Rosetta Books, LLC. ISBN 0-7953-0652-0.

[15] Carl J. Schneider \& Dorothy Schneider (2003). An Eyewitness History-World war ii. Facts on File, Inc. ISBN-10: 0-8160-4484-8.

[16] Barry Youngerman (2008). Pandemics and Global Health. Facts on File, Inc. ISBN--13: 978--0-8160--7020--6.

[17] Kim R. Finer (2004). Deadly Diseases and Epidemics. Chelsea House Publishers. ISBN 0-79107594-X.

[18] Kupperberg, Paul. (2008). The Influenza Pandemic of 1918-1919. Chelsea House Publishing. ISBN: 978-0-7910-9640-6.

[19] Slavicek, Louise Chipley (2008). The Black Death. Chelsea House Publishing. ISBN: 978-0-79109649-9.

[20] William W. Lace (2008). The Indian Ocean Tsunami of 2004. Chelsea House Publishing. ISBN 978-0-7910-9642-0.

[21] Sisira jayasurya, \& Peter McCawley (2010). The Asian Tsunami, Aid and Reconstruction after a Disaster. Edward Elgar Publishing Limited. ISBN 9781848446922.

[22] Harry Spaling \& Bryan Vroom (2007). Environmental assessment after the 2004 tsunami: a case study, lessons and prospects. Impact Assessment and Project Appraisal, 25(1). DOI: 10.3152/146155107X190622.

[23] Zu, Z. Y., Jiang, M. D., Xu, P. P., Chen, W., Ni, Q. Q., Lu, G. M., \& Zhang, L. J. (2020). Coronavirus disease 2019 (COVID-19): a perspective from China. Radiology, 200490. DOI: Retrieved from: https://pubs.rsna.org/doi/pdf/10.1148/radiol.2020200490.

[24] Jones, D. S. (2020). History in a crisis-lessons for Covid-19. New England Journal of Medicine. DOI: 10.1056/NEJMp2004361.

[25] Singhal, T. (2020). A review of coronavirus disease-2019 (COVID-19). The Indian Journal of Pediatrics, 1-6. DOI: 10.1007/s12098-020-03263-6. 
[26] Shi, Z., \& Hu, Z. (2008). A review of studies on animal reservoirs of the SARS coronavirus. Virus research, 133(1), 74-87.

[27] Zhang, L., \& Liu, Y. (2020). Potential interventions for novel coronavirus in China: a systemic review. Journal of medical virology. DOI: 10.1002/jmv.25707.

[28] Sohrabi, C., Alsafi, Z., O’Neill, N., Khan, M., Kerwan, A., Al-Jabir, A., \& Agha, R. (2020). World Health Organization declares global emergency: A review of the 2019 novel coronavirus (COVID19). International Journal of Surgery. DOI: 10.1016/j.ijsu.2020.02.034.

[29] Singhal, T. (2020). A review of coronavirus disease-2019 (COVID-19). The Indian Journal of Pediatrics, 1-6. DOI: 10.1007/s12098-020-03263-6.

[30] Tabari, P., Amini, M., Moghadami, M., \& Moosavi, M. (2020). Nations' Responses and Control Measures in Confrontation with the Novel Coronavirus Disease (COVID-19) Outbreak: A Rapid Review. DOI:10.20944/preprints/202003.0328.v1.

[31] Ramalingam, B., Wild, L., \& Ferrari, M. (2020). Adaptive leadership in the coronavirus response. Retrieved from: https://www.odi.org/sites/odi.org.uk/files/resourcedocuments $/ 032020$ pogo_coronavirus adaptation.pdf.

[32] Gostin, L. O., \& Friedman, E. A. (2014). Ebola: a crisis in global health leadership. The Lancet, 384(9951), 1323-1325. DOI: https://doi.org/10.1016/S0140-6736(14)61791-8.

[33] MacPhee, M., Chang, L., Lee, D., \& Spiri, W. (2013). Global health care leadership development: trends to consider. Journal of Healthcare Leadership, 5(1), 21-29. DOI: http://dx.doi.org./10.2147/JHL.S23010.

[34] Moore, M., Gould, P., \& Keary, B. S. (2003). Global urbanization and impact on health. International journal of hygiene and environmental health, 206(4-5), 269-278.

[35] Crosby, B. C., \& Bryson, J. M. (2005). Leadership for the common good: Tackling public problems in a shared-power world. John Wiley \& Sons.

[36] Frenk, J. (2010). The global health system: strengthening national health systems as the next step for global progress. PLoS medicine, 7(1), e1000089.

[37] Rapport, D. J., \& Maffi, L. (2011). Eco-cultural health, global health, and sustainability. Ecological Research, 26(6), 1039-1049. DOI: 10.1007/s11284-010-0703-5.

[38] John Nirenberg (2002). Global Leadership. Capstone Publishing, ISBN 1-84112-356-0.

[39] William H. Foege (2005). Global Health Leadership and Management. A Wiley Imprint. ISBN13 978-0-7879-7153-3.

[40] Kimbasomba, R. (2003). Political Leadership and State Building in a Post-War DRC. Institute for Global Dialogue.

[41] Raj, K. \& Aithal, P. S. (2020). The Post COVID-19 World: Efforts Needed to Build Back a More Resilient Society. International Journal of Case Studies in Business, IT, and Education (IJCSBE), 4(1), 88-93. DOI: http://doi.org/10.5281/zenodo.3783563.

$* * * * * * * * * * * * * * * * * *$ 